\title{
Gendering Expectations: Genre and Allegory in Readings of Thelma and Louise
}

\section{Aspasia Kotsopoulos}

Reflecting on the vociferous attention her film received, screenwriter Callie Khouri says that the social climate into which Thelma and Louise (1991) was released largely explains the furor around it. This was the year of the Anita Hill/Clarence Thomas case, which drew public attention to the issue of sexual harassment in the workplace. In the American media and in politics, women's issues were constantly under scrutiny. "There was such a backlash around the Equal Rights Amendment and the bill on abortion," remembers Khouri. "The atmosphere became so hysterical, like men imagined that women were going to be storming their bathrooms!"' Against this background of hysteria and backlash, Thelma and Louise emerges as testimony - a document of the times that effectively crystallizes the gender wars of that era.

In her book Backlash: The Undeclared War Against American Women, which documents the antifeminist backlash of the ' 80 s, Susan Faludi describes this cultural phenomenon as a flaring up of hostility towards feminism, occurring in periods in which women are seen as making - either real or imagined -

headway towards autonomy. ${ }^{2}$ Backlash suggests just how much definitions of femininity have become contested in the last two decades. Mia Carter points out that the backlash against Thelma and Louise during its reception was indicative of male critics' anxiety about feminism and their inability to accept that "things have changed," that "women, whether Khouri's mythological heroines or those among Thelma and Louise's passionate audience, are no longer silent, passive creatures." ${ }^{3}$ The reaction against feminism and against a film like Thelma and Louise demonstrates the degree to which women's movements have been successful in challenging traditional assumptions.

Thelma and Louise is a backlash representation but not in the usual sense - not at as an instance but as a fantasy enactment of backlash as experienced by women. The film maps women's experience of backlash from the moment in which the two women begin to assert themselves to the moment in which force is used to stop them. In allegorical fashion, the film plays out the process by which women's challenges to authority have resulted in a breakdown of consensus. The film gives symbolic expression to women's worst fears about backlash, before that expression is contained. Like Basic Instinct (1992), Fatal Attraction (1987) or The Temp (1993), Thelma and Louise may be reassuring to those who are committed to patriarchal authority and who are, consequently, disturbed by Thelma and Louise's transgression. Like these other films, Thelma and Louise may very well be read as an endorsement of backlash, as a warning 
to women who seek autonomy. Through the two women's deaths, the film does indeed reinforce the status quo. But this kind of conservative reading is rendered problematic because the film draws upon women's experiences as raw material for its fantasy. This is contrary to the backlash films mentioned, which speak solely from, to and about patriarchal anxieties over liberated women. ${ }^{4}$ Within this volatile ideological climate, Thelma and Louise becomes meaningful for an astonishing array of positions. This paper analyzes the film as a confused and baffled response to its own historical situation.

Along these lines, Thelma and Louise displays a consciousness of popularized feminist concerns, and seeks to incorporate such discourses while simultaneously adhering to the contradictory institutional demands of Hollywood filmmaking - that is, the demands for established forms and genres, as well as for novelty and contemporeinity. According to Christine Gledhill, while Hollywood production is indeed formula-bound, the drive to appear contemporary and innovative necessitates that even the most formulaic of plots must address, however obliquely, the topical issues of the day and offer new approaches to old genres. ${ }^{5}$

Besides addressing issues of interest to the women's movement, one of Hollywood's other recent nods to feminism has been to insert women into protagonist roles in traditionally male genres such as the Western (e.g., Bad Girls [1994]; The Quick and the Dead [1995]) or the detective thriller (e.g., Black Widow [1987], Blue Steel [1990]; The Silence of the Lambs [1991]; Copy Cat [1995]). As a road movie, Thelma and Louise belongs to this recent trend in Hollywood filmmaking. The road movie thematizes transformation through journey, with the main characters' movement from a familiar context to an unfamiliar space leading to personal discovery. Combining aspects of the buddy film, the outlaw couple film and the Western, the road movie often traces the picaresque adventures of two male friends as they bond across a natural landscape and through their mutual disregard for women and social institutions, in particular the law and community. Whether on the road as in Easy Rider (1969) or the wide-open range as in Butch Cassidy and the Sundance Kid (1969), these men are romantic outsiders unable to live within society and its rules, rebelliously seeking freedom from social convention. Paradoxically and typically, these characters are conventional themselves. They are hardly transgressive since, ultimately, they help to perpetuate closely held American myths about free will, rugged individualism and self-reliance.

Thelma and Louise draws upon road-movie codes, parachuting women into a traditionally male genre, to mobilize the desires of its contemporary female audience. The intersection of gender and gente inflects this film so that it speaks about ideological struggles in the late ' 80 s/early ' 90 s. The road movie regenerates itself to become a fantasy enactment of recent social conflict over 
notions of the law, gender and heterosexual relations. Thelma and Louise aptly illustrates Gledhill's notion of textual negotiation. As a generic hybrid, this film blends aspects of the road movie and the woman's film, offering gender-bending twists to old Hollywood conventions while also acknowledging popular feminist concerns around male violence against women. ${ }^{6}$ Yet genre also socializes us towards specific expectations. What happens when those expectations are not met?

The issue of violence places Thelma and Louise and others like it within the context of mainstream battle-of-the-sexes rhetoric. As a hegemonic strategy, "battle of the sexes" works to obscure feminist concerns with structural, gender-based inequalities. Battle of the sexes implies a natural, inevitable conflict abstracted from historical and systemic conditions. Moreover, it suggests a power struggle for the supremacy of one sex over the other, and perpetuates the misogynist stereotype of the feminist as a castrating bitch or - to use a term that had special currency during the release of Thelma and Louise - a "feminazi" " on and off the screen. This is not the only public discourse in which to situate these films. In recent years, women's movements in Canada and the United States have raised awareness on women's issues. Sexual harassment, date rape and domestic violence have been on the public agenda - they are popular issues that twenty-five years ago had no vocabulary. Women's movements have also brought attention to the ways in which social institutions often fail to protect women against male abuses in the workplace and in the home. Issues once associated with feminism only are now daily concerns in Canada and in the United States, regardless of how women and men situate themselves in relation to feminism. Films like Thelma and Louise represent the impact of feminist thought on public discussion.

The film attempts to negotiate the concerns outlined, raising topical questions about male violence against women, women and the law, heterosexual relations, and relationships between women. The film also works within ideological and generic parameters that limit its engagement with these social issues, generating meanings that are, in some cases, contradictory, and in others, clearly hegemonic. The symbolic treatment of gender relations and women's issues is potentially ambiguous - and therefore politically dubious in that it depends upon an interpretive strategy sensitive to allegory to successfully align viewers' perspectives with the protagonists', creating identification and empathy. Similarly, the interaction of gender and genre confounds expectations - and depending on how wedded one is to convention - produces readings that either decry or celebrate gender/genre transgressions. Given these factors, the diverse and diametrically opposed readings ascribed to Thelma and Louise, especially amongst feminists, make it an excellent example for engaging with questions around meaning and polysemy. ${ }^{8}$ 
The film's reception in particular has been well-documented. ${ }^{9}$ Here, academic critics as well as film reviewers pay attention to the gendering of readings, showing that interpretations of Thelma and Louise have been split along gender lines, with male critics decrying the film as an example of violent, battle-of-the-sexes male-bashing and a threat to American moral standards, and female critics arguing that the film addresses the social experiences of American women, expressing their concerns about sexual harassment and rape, and the law's insensitive treatment of women victimized by such crimes. The latter are issues that, Mia Carter points out, male critics often ignore, focusing instead on the film's representation of men. ${ }^{10}$ Indeed, Brenda Cooper's 1999 analysis of student responses to Thelma and Louise uncovers the same gender split.

A less-documented aspect of reception has been the split amongst feminists. Some feminist critics such as Alice Cross and Pat Dowell ${ }^{11}$ maintain that Thelma and Louise is reactionary and even offensive to women (e.g., the film is nothing more than a regressive male-buddy film in female drag; the film acts as a warning to women who challenge the status quo), while others, such as Mia Carter, Patricia Mann, Martha Minow, Susan Morrison, and Elizabeth V. Spelman assert its progressive qualities, its potential to open readings for female and/or feminist viewers. To make a progressive reading, each of these critics raise important points: Carter suggests that readings must pay attention to what male critics ignore in their interpretations; Morrison argues the film must be read in the context of the woman's film rather than the road movie; Minow and Spelman observe that readings of the film depend on how one situates oneself in relation to the law and authority; and Mann maintains the film must be read allegorically as a parable for our times. She notes that literal readings of the film have resulted in "an anxious and hostile torrent" from "sophisticated reviewers who usually accept the brutality and anarchy of contemporary films as unobjectionable cultural and political tropes [but] found it difficult to respond to the narrative of Thelma and Louise metaphorically."12

Thelma and Louise engages with each of the ideological agendas various critics impart to it. The result is that Thelma and Louise presents us with a layered, polysemic essay on contemporary gender relations. My response to previous writings will be to bear in mind the textual qualities that make both reactionary and progressive claims on the film possible. I want to hold the text accountable, in some measure, for the politically opposed readings it has produced. The focus on reception, specifically on the gender of audience members, overlooks a consideration of the text and the way in which it is itself contradictory and ambiguous - something which individuals involved with the production readily admit. 


\section{PRODUCTION AND PUBLICITY}

A look at press accounts of the production of Thelma and Louise and at promotional publicity surrounding the film and its stars sketches out the apparent conditions under which this film was made. While the circulation of such information would have an impact on readings, I am more concerned with how press accounts may suggest conflicts during the making of Thelma and Louise that may have become manifest in the text.

Discussions of the screenplay in mainstream media accounts focus on the feminism of its author, Callie Khouri, and on industry interest in the story. Khouri was a first-time screenwriter when she penned the Oscar-winning screenplay for Thelma and Louise. In interviews, Khouri identifies herself as a feminist, but also claims she did not write Thelma and Louise with the intention of producing a feminist tract, contrary to what her critics might claim: "I am a feminist, so clearly it is going to have my point of view. But this is a movie about outlaws, and it's not fair to judge it in terms of feminism." 3 Khouri explains that her concern with the lack of respectable film roles for women led her to write the screenplay. ${ }^{14}$ In 1989 , director Ridley Scott, known for his genre-twisting in films such as Alien (1979) and Blade Runner (1982), optioned her script with plans to use it as a project for his production company. ${ }^{15}$ According to New York Times writer Larry Rohter, "[Khouri's script] became the talk of Hollywood - or at least of agents with female clients," and "attracted the attention of the four big studios and big stars like Goldie Hawn, Cher and Michelle Pfeiffer." ${ }^{\prime 6}$ Scott says he had no plans to direct the film himself, until he shopped the screenplay around to various top directors and found their reactions so positive, he decided he would take it on as director. ${ }^{17}$

Reports in popular magazines and newspapers suggest that the screenplay's circulation within the industry did not generate controversy but genuine interest. Given that Thelma and Louise was the first screenplay of a virtual unknown, such interest is remarkable and speaks to industry confidence in the wide appeal the film could garner. From the perspective of female stars, the screenplay no doubt was refreshing in that it featured not one but two female roles in a narrative that put women front and centre. As actor Geena Davis, who plays Thelma, comments, "I had been hearing about this great script with not one but two great parts for women, which is a very unusual event ... [I] just loved both the parts. Its not often you see parts for two fully realized women characters and have a movie be about women's adventures and journeys." ${ }^{18}$ This discourse around the screenplay suggests there were no concerns that the film would alienate audiences. In a 1996 interview, actor Susan Sarandon, who plays Louise, comments that at the time she was making Thelma and Louise, she had no idea it would inspire the heated debate that it did, implying that out- 
cry over the film came as a surprise. According to Sarandon, "I don't quite understand what happened, because I thought it was just a cowboy movie with trucks and women instead of guys and horses." ${ }^{19}$ Khouri expresses similar dismay, stating, "I couldn't keep up with the number of people who attacked me. I didn't think what I wrote was even mildly offensive, and all these people were calling me a fascist."20

Relying on hindsight and media accounts of the film's production is problematic. On the one hand, it may be that publicity was controlled so as to contain any mention of conflicts over the script during the filming. On the other hand, it may be that confidence in the script was so high that concerns, if there were any, were minor. In any case, press coverage gives a picture of an ordinary, routine and uneventful production - surprising considering the controversy the film subsequently generated. Rohter even reports that MGM/Pathé, the studio that took on Scott and Thelma and Louise, "promised not to force Ms. Khouri and Mr. Scott to tinker with the script or change the dramatic conclusion."21

While this is somewhat astonishing, it isn't if one considers just how ambiguous Khouri's screenplay is. As Harvey R. Greenberg puts it, "Khouri's script ... enhances the film's ambiguous openness for interpretation by sharply scanting information of the protagonist[s']" prior lives, except for a few bold strokes. What one gets of the women is what one sees."22 Indeed, interviews with Sarandon suggest the script was so full of holes the actors "had to come up with so much backstory" in order to find motivation for the characters. ${ }^{23}$ Discussing the emotional logic behind Louise's shooting of Harlan, Sarandon explains that a backstory had to be constructed: it was decided that Louise was re-living her rape in Texas, after seeing her friend humiliated in a similar way. ${ }^{24}$ In the same interview, Sarandon cites other scenes that were either rewritten or supplied as backstory, including Thelma and Louise's different methods of packing, as well as the actual shooting. According to Sarandon, there was discussion as to whether or not the shooting should be interpreted as an assassination, indicating anxiety with the scene, an anxiety that would later be echoed more vociferously in the film's critical reception. "What I didn't want it to be, which was discussed, was an assassination; I didn't feel [Louise] was together enough to do that," explains Sarandon. "When she says, 'Buddy, you keep your mouth shut,' after he's obviously dead, it shows she's gone off a bit." 25 In a later interview, Sarandon states, "In the script, she takes a stance and executes him. I couldn't imagine her taking that stance. I wanted to change it so she just brings the gun up and it goes off - which is what happens sometimes with guns." 26 Sarandon's comments are revealing. While there doesn't appear to have been concern over the screenplay in the sense that it might be offensive or alienating, there was nonetheless a concern with its ambiguity and with how the 
shooting might be read. Significantly, this concern is framed in terms of character motivation rather than ideology or politics.

\section{KNOWING ME KNOWING YOU}

Independence and freedom are central to Thelma and Louise. ${ }^{27}$ The film's opening sequence sets up the primary conflict that motivates the narrative: a woman's desire for freedom from male authority. The sequence cuts between Louise working at the restaurant and Thelma trying to contend with her domineering, loudmouthed husband, Daryl. The mise-en-scène of the opening sequence suggests the entrapment of the two women. Louise winds her way between tables and customers, and Thelma contends with the domestic chaos of her cramped suburban kitchen. Both women move in spaces that are cluttered, and both women are tightly framed by the camera.

On the telephone, Louise tells Thelma she wants to get out of town to punish her boyfriend who is unwilling to make a commitment to her. As Daryl, who cannot find his socks, blusters in the background, Louise cajoles Thelma, calling her a "little housewife," in an effort to persuade her to abandon Daryl for the weekend. Thelma replies that she has not asked his permission yet, prompting Louise to inquire impatiently and accusingly, "Is he your husband or your father?" Louise's question signals the film's first challenge to traditional gender relations. While in another historical context, one might have answered there is no difference, in a ' 90 s context the question brings attention to the ongoing re-definition of heterosexual relations occurring in the wake of secondwave feminism. However, Daryl is characterized as a buffoon rather than a menace, and this sets off several possible meanings.

Mann comments that Daryl's blustering "suggests the empty quality of patriarchal authority" in contemporary America. ${ }^{28}$ This characterization of Daryl also lessens the threat the film poses to sexist male audience members, who can breath a sigh of relief: they are not him since Daryl's sexism is excessive and comical while theirs is reasonable and normal (read: invisible). Cooper sees the film's "mockery" of "macho stereotypes" as constructing a female gaze that challenges patriarchal authority. ${ }^{29}$ While I agree that male stereotypes such as Daryl, as well as others (e.g., the working-class rapist, the obnoxious truck driver, the arrogant cop, the seductive cowboy), invites women's recognition, I am not convinced these pose a challenge, but instead, may be recuperative. The stereotypes have the potential to distance the men on the screen from men in real life and from those sitting in the audience, rendering the fantasy safe. The problem becomes some men rather than an entire society founded on patriarchal assumptions, and criticism is rechanneled so that it is directed at male caricatures like Daryl. 
Moreover, the conflicts that emerge from Thelma's oppressive domestic situation, however comical, help trigger her search for autonomy, suggesting that a woman's desire for self-determination is in need of exterior justification - In this case, an extreme jerk for a husband. The implication is that if Daryl had been different, Thelma's inclination toward female autonomy might never have existed. As Thelma later says to a police officer who has a wife, "You be sweet to her. My husband wasn't and look how I turned out." However, Daryl's demands on Thelma, even if they appear ideologically contradictory and are stretched to the point of ridiculousness, still speak to frustrations expressed in many other examples of women's popular cultural practices such as the soap opera, the fashion magazine and the woman's film. The familiarity and recognizability of the question Louise asks ("Is he your husband or your father?") is important, then, in that it links up with a host of heterosexual women's frustrations - from unsatisfying relationships with men to an unfair share of the housework to the vague feeling that there could be more to life - and opens space for a negotiation of meanings that may relate allegorically to broader women's experiences.

While Louise starts off as the stronger, more experienced, and independent-minded of the two women, the story belongs to Thelma and her transformation from a meek, obliging housewife who has never been out of town without her husband, to a (quasi-)feminist, gun-wielding, whiskey-drinking outlaw. Still, Louise is set up, initially, as Thelma's older, more knowledgeable role model. At the beginning of the road trip, Thelma, with unlit cigarette, emulates Louise smoking. "Hey, I'm Louise," she says to her friend, signifying her desire to be like Louise, to know what she knows. The naïve woman's fascination with the experienced woman links Thelma and Louise to previous examples of the woman's film such as Rebecca (1939), All About Eve (1950) and Desperately Seeking Susan (1985) ${ }^{30}$ While the first two films render this fascination problematic, the latter one like Thelma and Louise valorizes it and encourages it. Indeed, after Thelma's admission of wanting to be like Louise, the film works as wish-fulfillment, much like the bump on the head Roberta/Roseanna Arquette receives which makes her believe she is Susan/Madonna. It is not surprising, then, that Daryl refers to Louise as a "bad influence" on Thelma. Moreover, the two women resemble each other from the start (both have red hair, with Geena Davis dying hers for the part of Thelma), and increasingly so as the narrative progresses. At the outset of the trip, Thelma wears big hair and a frilly dress, while Louise sports a tidy hairdo and chic spangled jacket. While on the run, each woman discards the accoutrements of femininity - Thelma, her frilly dress and Louise, her jewelry and lipstick. Through a process of deglamorization, they come to look more and more like each other, in jeans, T-shirts and loose hair. 
Journalists writing about Davis and Sarandon at the time of the film's release want to strongly identify the two actors with their respective characters. Writers often construct Sarandon as a rarity in Hollywood: a mature woman who still gets good jobs and is allowed to be sexy and smart; and a positive role model and inspiration for younger women. ${ }^{31}$ This latter discourse around Sarandon frames media accounts of the relationship between Davis and Sarandon during the film's making. People Weekly's Jim Jerome reports that the film represented a "chance for Davis to bond with a fellow actress" and claims "Sarandon became a role model for Davis." ${ }^{32}$ Both these comments are interesting given that the film is about female bonding and about the naïve Thelma's transformation into her role model, the worldly and wise Louise. Davis is quoted speaking admiringly of her co-star: "She's great and strong and wonderful. I used to tease her and say, 'When can I be like you?"'33 Premiere's Rachel Abramowitz goes so far as to imply that Davis's feminist consciousness was raised because of her experiences making this film: "Ever since Thelma and Louise, Davis has been more politically engaged, speaking mostly on women's rights. When Faludi's Backlash appeared [the same year as Thelma and Louise], Davis sent out copies to a number of Hollywood colleagues. She's taken more public stands." ${ }^{34}$ Parallels between Davis and Thelma seem hard to resist, and Davis is sometimes described in words that could be used to describe Thelma, particularly around her desire to be free and in charge of her life. ${ }^{35}$ As Jerome writes, "[F]or Davis - as for Thelma - the name of the game is independence ...." 36

Key to Thelma's transformation is the acquisition of the knowledge that Louise possesses, while the knowledge that passes from Louise to Thelma is never explicitly spoken in the film. What Louise knows (from an experience in Texas to which she refuses to refer) and what Thelma subsequently learns at the road house, where she narrowly escapes a rape, can be read symbolically as a female initiation into patriarchal relations. Feminist critics such as Rhona Berenstein, Karen Hollinger, Alison Light, Susan Morrison, and Tania Modleski have written about Rebecca in this way, suggesting that the girl (we never learn her name) comes into maturity once she learns the terrible truth about the position of women in a patriarchal culture, and subsequently must choose between the worldly and independent Rebecca, the image she wishes to become and who threatens patriarchal authority, and Maxim, who represents that authority and whose approval the girl seeks. In the end, she chooses the latter. While comparing the narrative of a gothic romance to that of a road movie may seem like a stretch, it may be that feminizing a male genre involves the incorporation of narrative codes that are familiar to female audiences, that draw from women's genres, and that speak in some way to shared anxieties arising from similar social experiences. 
Thelma learns the terrible truth about patriarchal dominance of which Loujse never speaks. With this knowledge, she rejects her husband, her former self as a "little housewife" and chooses Louise over patriarchal authority. More correctly, the women choose each other, an aspect of the film that appealed strongly to female viewers, as Cooper was able to prove in her reception study. Moreover, Thelma and Louise's rejection of patriarchal authority and their refusal to give heterosexual relations primacy over their friendship has led to readings of the film as a lesbian coming-out story, ${ }^{37}$ which not only widens the film's address, but further accentuates the threat the women's relationship poses to patriarchal authority, as represented in the narrative by the law.

\section{RAPE AND ALLEGORY}

The road to Thelma's transformation is a treacherous one placing her further and further outside the law. It begins at the road house where the two women have stopped to have a drink on their way to their destination. Here, an increasingly drunk Thelma dances and flirts with the stranger Harlan, much to Louise's annoyance. Later, Harlan beats and tries to rape Thelma in the parking lot, until Louise comes to the rescue with the gun Thelma packed for the trip in case of "psycho killers". Thelma's frightened imagination at the start of the trip illustrates what Carter calls "the truth of women's grim social awareness; too often we are afraid." ${ }^{38}$ Indeed, Thelma's fears at the beginning of the trip become manifested in the form of the rapist Harlan. When Harlan shows no remorse for his attack, and instead hurls sexual insults at the women, Louise shoots him dead.

Harlan's murder is one of the more difficult scenes to read in the film and has produced the most controversy, generating conflicting interpretations. The scene produces at least two possible readings, one literal, the other allegorical, each with different political implications. The literal reading interprets the attempted rape and subsequent murder as an advertisement for vigilantism: the scene advocates that individuals take the law into their own hands, acting as judge, jury and executioner. That Louise shoots Harlan in response to verbal rather than physical abuse makes it difficult, according to these accounts, to justify the punishment she metes out. Moreover, the scene draws an equivalence between the violence of language and the violence of rape so that two key feminist concerns - male violence against women and the power of language to perpetuate misogyny - become conflated instead of remaining separate but connected. This conflation gives grounds to criticize feminists as politicallycorrect, humorless feminazis who take everything too seriously (e.g., you can't say anything these days for fear a feminazi might slap you with a harassment suit). In addition, the popular recognition of rape as a feminist issue links the 
scene to radical feminism's "kill-your-rapist" rhetoric," which has been attacked in the mainstream, interpreted in a battle-of-the-sexes context, and has served to further marginalize feminisms of all kinds.

This literal reading may be further divided into those that are feminist and those that are anti-feminist, with both, ironically enough, rejecting the film as dangerous and reactionary. In a literal feminist reading, the scene is damaging to feminism and to women because it misrepresents feminist concerns with language and violence, and plays into the hands of conservatives who fear that the feminazis are going too far and must be stopped (by film's end, they are). In a literal anti-feminist reading, the scene validates hegemonic anxieties about unruly, hysterical feminists who are getting out of control and must be reined in (by the conclusion, they are). As Dowell remarks, "Thelma and Louise have made their most indelible mark as cautionary figures for men. (Less noted is the fact that they serve as a warning to women, too.)" 40

When read allegorically, however, the scene has altogether different ideological implications. Rather than conflating issues of sexist language and male violence against women, an allegorical reading sees these two feminist concerns as metonymic representations in the film. Metonymy works by using a part or element of something to stand in for the whole. Metonyms depend upon our skill at constructing the rest from the part we have been given. In Thelma and Louise, the attempted rape and the subsequent verbal attack are parts that make up the whole of women's social experiences in a sexist society. With this in mind, Harlan's death takes on particular connotations and acts as a lightning rod, drawing to it social questions that the film wants to explore. As Putnam explains it, the murder is committed

... to avenge not only this outrage [the verbal assault after the sexual assault] but all of the little rapes, the everyday usurpations of female autonomy that all women know. Viewed allegorically, the scene portrays the ritual re-enactment of cultural conflicts at the heart of women's everyday lives. The actual social world is magnified, symbolized, throughout this sequence of crime and redress. ${ }^{41}$

Harlan represents every misogynist we have ever encountered. In the role of feminist avenger, Louise shoots Harlan for Thelma, and as we later learn, for herself in reaction to a past trauma of which she will not speak. Harlan is symbolically exorcised, cast out, by Louise's bullet in punishment for all the times a woman's agency has been denied, either through violence or language. The film illustrates in larger-than-life proportions the interconnectedness of sexist language and male violence against women, and the ways in which women are routinely dismissed, silenced, or humiliated. Read allegorically, the scene 
demonstrates Thelma and Louise's right to say no to all forms of misogyny and to be heard rather than ignored. The actual use of this reading strategy bears up in Cooper's research. She found that female students interpreted the shooting "as the desire to overcome powerlessness" in a system that leaves women with "no voice" and "few choices". ${ }^{42}$ Most male students in the study were unable to make the metonymic links necessary for an allegorical reading. To put it another way, the female students, like the actors, supplied the backstory the film needed, while the male students could not.

Along these lines, the waitress at the road house offers the best reading of Harlan's murder. Interpretations of the crime depend upon the degree to which the viewer is willing to metonymically relate the waitress's comments to the experiences of Thelma and Louise and women generally. During the police investigation, the waitress tells the key investigator that she "hope[s] it was his wife who did it" and that "I coulda told you he'd end up buying it." Without saying anything explicit, the waitress knows (and presumably, the women in the audience know) what kind of man Harlan is, and that sooner or later (we hope) he would pay for it. In this reading, the experiences of women are the focus and not the murder itself (which, conversely, tends to be the case in the literal readings). As Minow and Spelman state, "[Louise] shoots in judgment; she has judged that he will not stop this behaviour and that even if Thelma gets away, other women will be victimized." 43

Elayne Rapping has written that Louise's shooting of Harlan during the verbal attack instead of the sexual assault "muddies the political waters hopelessly." ${ }^{.44}$ As it is, the shooting opens Thelma and Louise to various interpretations, resulting in a relativism that renders feminist, oppositional claims on the film as legitimate as hegemonic ones. Still, to see a man punished by a woman for his sexism rather than a woman for her sexuality gives the film a unique political resonance. While the fate of the femme fatale rarely inspires the righteous indignation of male film reviewers, it is interesting that the death of a misogynist asshole could inspire an outpouring of moral outrage. Comments by Davis and Khouri aptly sum up the situation: defending the film against charges of male-bashing, Davis argued, "If you're feeling threatened, you are identifying with the wrong character," and Khouri, maintaining that the film is not hostile toward men, stated "I think it is hostile toward idiots." ${ }^{45}$

\section{WOMEN AND THE LAW}

Thelma and Louise flee the crime scene because of Louise's conviction that they cannot go to the police. At various points the option of turning to the police for help is presented either by Thelma or by Hal/Harvey Keitel, the sympathetic cop, who wants to help the women at the same time that he is tracking 
them down, bringing with him the force of the law. Thelma and Louise displays a consciousness of contemporary feminist critiques of the law and its insensitive, inadequate treatment of women who have experienced male violence. Moreover, the film suggests that Louise has been mishandled by the law previously in Texas. She knows they will not be believed. They have been drinking and Thelma was seen flirting with Harlan. When Thelma first mentions the idea of going to the police and explaining to them what happened, Louise says the police wouldn't believe her because "a hundred goddamn people saw you dancing cheek to cheek ... We don't live in that kind of world!" Thelma and Louise works from our knowledge of recent, publicized rape trials where women have been required to prove they did not provoke or deserve the assault. As Carter points out,

The sad truths of the real world and the disappointing scenarios of too many recent rape trials have taught women that they will not be believed, however battered and bruised and no matter how well-witnessed the crime ... Many women understand all too well why Thelma and Louise fled. ${ }^{46}$

The question of whether or not Thelma was asking for it echoes public discussions of where the blame lies in rape cases. ${ }^{47}$ In this way, the women's personal and private conversation become a social conversation. Their conversations inside the car work in the same way that conversations do in the soap opera, with characters recounting dramatic events through fragments of conversation in an attempt to make sense of them and give them meaning. Thelma and Louise attempts to blend (masculine) action with (feminine) conversation which is indicative of the textual negotiations the film enters into as it tries to feminize the road movie through codes more familiar in women's genres such as the soap opera and the woman's film. Minow and Spelman comment that

Although the law put them beyond its ken and beyond its protection, Thelma and Louise engage in a continual discussion about blame and guilt, and about responsibility and obedience. Placing at the center these outlaws' views of law and morality displaces societal images of the outlaw as amoral. Their own moral judgments afford a critical perspective on law and conventional morality. ${ }^{48}$

Considerable negotiation occurs between differing viewpoints on issues of blame and responsibility. However, both Thelma and Louise eventually reject the notion that a woman's behaviour is in any way culpable in her own assault. Furthermore, despite the best intentions of individuals like Hal, the film is firm in its conviction that institutional law does not work on women's behalf, but 
instead, turns the victims into criminals, forcing Thelma and Louise to take the law into their own hands.

The law works to define notions of criminality and justice, which are often gendered concepts. To stress the point, the film sets up a contradiction between the way in which the film's police and legal discourses define Thelma and Louise, and the way in which the two women are constructed for the audience. We are given two views of Thelma and Louise, which complicates our relationship to the women and to the law, no matter where we may stand on the issues portrayed. The events leading up to and including Thelma's robbery of the convenience store provide a good example. Here, Thelma and Louise pick up a charming hitchhiker named J.D./Brad Pitt, with whom Thelma has a fling (the film's way of demonstrating what consensual sex between strangers looks like), during which he explains to her the patter he uses when conducting an armed robbery. The morning after, J.D. steals Louise's $\$ 6,700$ in savings, the money the two women were using to get to Mexico. When the women discover the theft, Louise is devastated, about to give in to the law, until Thelma takes charge, and robs a convenience store. When the hold-up occurs, the audience is positioned outside the store with Louise, who is unaware of Thelma's actions until she comes running out of the store telling Louise to start the car. Thelma's behaviour here is unexpected since, up until this point, she has been passive with Louise making all the plans.

Thelma's crime is captured on the store video. The first time the audience actually sees the crime is on this video, which the police investigators and Thelma's husband are watching as evidence of the two women's criminal inclinations. The scene makes us privy to the kinds of interpretations that the spectacle of Thelma - conducting an armed robbery using J.D.'s self-assured patter - can produce. When read through the lens of the law, Thelma, and by extension, Louise are criminals, armed and dangerous. But an alternative reading presents itself, arising from the viewer's role as witness to the social experiences that led to their criminal behaviour (i.e., Harlan's murder, the convenience-store robbery, the destruction of the truck driver's rig, the locking of the officer in the trunk of his cruiser). By positioning the viewer as witness to the crimes, the film presents a reading of Thelma and Louise as women misdefined by the law and wronged by a sexist society. As Minow and Spelman point out,

The law has its own rules about what are the relevant and irrelevant facts about people's lives. The price of being protected by the law in court is to surrender control over the telling of your story. ... Had Thelma and Louise turned themselves over to the law - whether to the sheriff or to an attorney - they would have become subject to constraints much 
like those from which they found themselves fleeing, constraints which among other things make their versions of themselves and of the world irrelevant. ${ }^{49}$

The law attempts to seize control of Thelma and Louise's story, in order to put in its place a version of the two women that is in keeping with received notions of criminal women. "I almost feel like I know you, Louise," says detective Hal. "I know what happened to you in Texas." Quick to reply, Louise says, "You don't know me," challenging Hal's claim to knowledge of her story. To further accentuate the conflicting versions available of Thelma and Louise, the scene of the police watching the spectacle of the robbery on video is followed by a scene in which Louise admonishes Thelma not to litter. While this is a minor incident, its inclusion serves to illustrate a point: these women are not without morals nor a sense of social responsibility.

Making the audience privy to Thelma and Louise's points of view complicates viewers' attitudes towards the law and other social institutions. Louise is keenly aware of how the law is defining her and positioning her in relation to the rest of society, whereas Thelma has difficulty in apprehending the shift that has taken place in her social position. "We're fugitives now," says Louise to Thelma, "Start behaving like that." But what constitutes fugitive behaviour, and who gets to decide are questions that always hover on the surface and that also illustrate the film's strong links to the outlaw-couple film.

\section{THE FEMALE OUTLAW COUPLE}

The outlaw-couple film has its origins in the American, Depression-era gangster film, where the gangster is sympathetically portrayed as someone who overcomes class limitations and defies the class hierarchy of capitalist society. These films ask who is the bigger criminal, the gangster or the capitalist society? And where does responsibility for criminal behaviour lie, in the individual or the society? Thelma and Louise works in similar ways but as an indictment against patriarchy (as well as, though to a lesser degree, capitalism). Thelma and Louise demonstrates the way in which a Hollywood genre renews itself to become an enactment of contemporary social conflict. According to Glenn Man,

Analogous to such forbearers as Rico (Edward G. Robinson, Little Caesar 1930) and Tony Camonte (Paul Muni, Scarface 1932), who dare to disturb the hierarchy of class in society through criminal violence, Thelma and Louise disrupt their gendered placement in society and therefore must be brought to task or eliminated as threats to the status quo, the tradi- 
tional fate of all movie gangsters ... What once passed as social/class oppression in the genre now becomes a social/gender oppression in the 1990s. ${ }^{50}$

In gangster films featuring outlaw couples, the pair is forced to live outside society but not by choice. In films such as They Live By Night (1948), Gun Crazy (1949), Bonnie and Clyde (1967) and Thieves Like Us (1974), social forces are portrayed unsympathetically and the outlaw couples are romanticized because they are presented as victims of a corrupt society. As Ms. Magazine film reviewer Kathy Maoi states, "Thelma and Louise become outlaws not because they love violence, but because men won't leave them be." ${ }^{\text {I }}$ As an outlaw couple film, Thelma and Louise exposes the inadequacies of patriarchal society. In the end, society wins out and, as is tradition, the outlaw couple is destroyed.

Moreover, as a female same-sex outlaw couple, Thelma and Louise's threat is magnified. While their flouting of the law threatens authority in general terms, the fact of their femaleness increases their threat. Like (Arbuthnot and Seneca's argument about) Gentlemen Prefer Blondes (1953), Thelma and Louise is unique in that it presents us with a female friendship that is not tainted by jealousy or competition but instead is based on loyalty, caring, and mutual admiration. This is a departure from films that portray women in competition with each other for the attention of men or that render female same-sex identification as narcissistic or even pathological, as in All About Eve (1950) or Single White Female (1992). By contrast, Thelma and Louise emphasizes the women's allegiance to each other in a positive way, and as such, poses the ultimate threat to patriarchy - lesbianism and the elimination of the male, or more symbolically, of a reassuring patriarchal presence. ${ }^{52} \mathrm{Men}$ may bond with other men (with the unstated rule that they never have sex with each other) in the interests of shoring up misogyny and male dominance, as they do in the male buddy film or the film noir, but women are not to bond with other women, either as friends or especially as lovers, and they are not to put their relationships with women (if they are misguided enough to have any) above those with men. Doing so, makes outlaws of women.

Discussing the outlaw in American mythology, Minow and Spelman argue that our ability to accept outlaws as noble depends on how we judge the outlaws' worldview and their actions:

Viewers of Thelma and Louise who are ready to regard the two women as noble outlaws have to be able to think about both the women and those affected by their actions in fairly specific ways. Thelma and Louise have to be seen as acting, preferably self-consciously, in accordance with a just princi- 
ple or concern. The would-be rapist Harlan and others directly affected by the women's actions have to be seen as in some sense deserving what they got, whether or not the law prohibits their being treated that way. ${ }^{53}$

Minow and Spelman's conclusions aptly account for the competing readings available of Thelma and Louise, and bring us back to literal versus allegorical readings: in order to justify Louise's shooting of Harlan, the viewer is required to make metonymic links between other aspects of the film and the social world in which Thelma and Louise, and the female audience members live. Producing a reading that justifies Harlan's punishment is impossible without a sense of that social world, as Cooper found in her analysis of student responses to the film.

On their road trip, the women encounter a "miscellany of masculinity" from the would-be rapist Harlan, to the obnoxious truck driver, to the paternalistic Hal. ${ }^{54}$ As Ann Putnam notes, the two women travel through "a landscape awash in waves of pumping testosterone: spouting steam, spraying planes, spilling hoses, pumping oil riggers, and men pumping iron and pumping gas." 55 Thelma and Louise's personal moral code is not in keeping with that of the malc-dominated world in which they live but rather reflects their social experiences as women. Their defiance of conventional expectation is rendered all the more transgressive because they are women who reject traditional femininity. Because Thelma and Louise refuse to passively accept the routine victimization of women, they threaten patriarchal authority - an authority dependent, in part, upon women's quiescence. If a viewer is committed to the gender status quo, then Thelma and Louise is bound to be discomfiting, as its critical reception has indicated.

Along these lines, and as Minow and Spelman maintain, who the outlaw is also determines their status as noble or ignoble. ${ }^{56}$ In Thelma and Louise's case, we are referring to two, straight, white women from working-to-lower-middleclass backgrounds. What is the effect of their gender and social status on possible readings and on viewers' relationships to the two characters? The importation of women into a traditionally male genre requires a degree of genderbending accompanied by a sense of gender transgression. In this case, women, usually defined as having nurturing, non-violent, passive qualities, are committing crimes at gun-point, including acts of violence against domineering men. If onc is committed to male dominance, a certain amount of discomfort will be connected to the punishments Thelma and Louise mete out, making the two characters anything but noble in their affront to patriarchal authority. As Maoi comments, "Women can shoot a gun for the government and blow away anyone who threatens their men or their kids, but any 'heroine' who packs a pis- 
tol against systematic male violence is going to take some heat." ${ }^{57}$ In this reading, even the deaths of Thelma and Louise may not be cnough to quell fears of unruly women because the spectre of their example lingers, long after the projector stops. Thelma and Louise's gender transgression exceeds closure, and this is best exemplified by the way in which the film, after the two women have (presumably) plunged to their deaths in the Grand Canyon, reverts to a montage of narrative high points during the end credits, reminding the audience of the women's strength and exuberance.

Even if one is not committed to the status quo, it still may be difficult to produce a progressive reading. Thelma and Louise's gender transgression may work to produce diametrically opposed feminist readings which jeopardizes their status as noble outlaws, and which, broadly speaking, indicates struggles amongst feminists over issues of gender and representation. Are the characters' gender transgressions justified as an allegory for contemporary feminist concerns? Or are they an insult to women because the film masculinizes the female characters so that they resort to stereotypical masculine forms of behaviour in this case, aggression and gun-related violence - which feminists want to challenge? As an example of the latter concern, Dowell remarks that the film "does little more than fill a male formula with female forms." ${ }^{\$ 8}$ In light of this comment, it is difficult to regard Thelma and Louise as noble - never mind, feminist - outlaws.

My criticism of concerns such as Dowell's is not meant to invalidate them but to consider their implications. The concern with women behaving like men invites a discussion of notions of femininity and masculinity, as well as popular fantasy. The question is not whether or not Thelma and Louise are indeed behaving like men, but rather, how do definitions of appropriate gender behaviour impact on one's reading of the film as progressive or reactionary? And how might genre socialize us towards particular gender expectations? Comments such as Dowell's suggest there is behaviour acceptable for and essential to women and other behaviour that is not; and that there are genres more preferable for dramatizing women's fantasies than others. Taking the argument that Thelma and Louise are women in male drag suggests there is an essential femininity beneath their genre-induced, masculine masquerade. ${ }^{59}$ While feminist concerns with violence and aggression are not to be dismissed, comments about Thelma and Louise's masculinization inadvertently perpetuate patriarchal and essentialist-feminist myths about a feminine essence that is non-violent, self-sacrificing, nurturing, passive, non-aggressive ${ }^{60}{ }^{6}$ It is easy to see why the film produced unfavorable responses from both feminist/oppositional and conservative/hegemonic perspectives, making temporary and inadvertent allies out of the unlikeliest political groupings. 
Certainly, Thelma and Louise's class positions additionally impact on readings with contradictory effects. For instance, Minow and Spelman argue that the women's class backgrounds make the fantasy "more palatable to the middle-class audiences to whom the film is directed than if the heroines were solidly middle - or upper-middle class." ${ }^{61}$ The same can be said for the race of the two women, as well as their sexuality. (Imagine critical reception if Thelma and Louise had been black or explicitly identified as lesbians?) However, I am not convinced that the film's address works with respect to class in the way Minow and Spelman suggest. On the contrary, rather than being directed specifically at a middle-class audience, the film seeks to cut across class lines by speaking in classless terms about adult disillusionment - a problem in itself in that it feeds into the American myth of a classless society, and distracts from the economic and societal constraints on youthful hopes for the future. ${ }^{62}$

\section{RESISTANCE AND ADDRESS}

Thelma's fugitive status is directly proportional to her new-found self-determination. Each of Thelma's self-determining actions increases her threat to the social order: she decides to run to Mexico with Louise after she phones Daryl and tells him he is her husband not her father; she chooses to have sex with J.D., after which she "Finally understands what all the fuss is about;" she takes control of her situation by robbing the store to make sure she and Louise have money to complete their escape. She is no longer the woman Louise accused of "flaking out" every time she was in trouble. Having made the full transition to Louise-ness, Thelma wears her friend's jacket when, over the phone, she tells Daryl "to go fuck [him]self."

Thelma's transformation is made all the more transgressive given the class positions of the two heroines. Louise is a lower-income food-service worker while Thelma is a middle-income housewife. Their class status and social environment limited the choices they can make, leading to frustration and boredom. As Cathy Griggers points out,

They've been around long enough to know they haven't been far enough - not yet. And so they've got cabin fever - the desire to get out and to get away - if only for the weekend ... [Moreover, t] ] hey have cabin fever for different reasons. Thelma is fed up with housework, Louise with the salarywage exchange. The tips don't make up the difference. There's something missing, something left unmarked in the political economy of both the contemporary working singlewoman and the domestic housewife. ${ }^{63}$ 
Like the gangsters of Depression-era Hollywood, who also come from working or lower class backgrounds, Thelma and Louise transgress against the limitations of their class, as well as gender. Their flight from their social and economic positions is a fantasy that opens up the film's textual address for at least two reasons: first, it connects with the lived realities of its intended female audience in ways that acknowledge both the diversity of female social experiences and the commonalities that can bring women like Thelma and Louise together; second, it expands its address to include both women and men by tapping into adult fears that life has not lived up to society's promises. Feminist film critic Carol J. Clover rightly argues that

To focus, as the debate about Thelma and Louise did, on those men who disliked it is to miss what I think is the far more significant fact that large numbers of men both saw and did like it ... lots of men were evidently happy to enter into that very American fantasy [the buddy-escape plot] even when it is enacted by women, even when the particulars are female-specific (rape, macho husband, leering co-worker), and even when the inflection is remarkably feminist. And although the film showed signs of defensiveness on this point (the niceness of the Harvey Keitel figure struck me as something of a sop to men in the audience), it was on the whole surefooted in its assumption that its viewers, regardless of sex, would engage with the women's story. ${ }^{64}$

Clover maintains that attention to the gendering of readings has ignored this film's appeal for men. Even screenwriter Khouri points out that "during test screenings prior to the film's release, it scored the highest points amongst 25 -year-old males." ${ }^{65}$ Indeed, the sheer popularity of the film would indicate not all men found it difficult to relate to the story of Thelma and Louise. The film's confidence that it could appeal to viewers of both sexes is evidenced in the initial interest Hollywood heavyweights paid to the screenplay of Khouri, an unknown entity at the time.

As the narrative moves towards its conclusion, the film increasingly comes to speak about adult disappointment because, contrary to popular belief, we are not masters of our own destiny. There are forces beyond our control that limit our lives and the choices we can make. For instance, in a set of close-ups of the two women, whose faces dramatically fade into each other's, a Marianne Faithful song plays on the soundtrack: "At the age of 37 , she realized she'd never ride through Paris in a sports car with the warm wind in her hair." This melancholy song comments on the plight of Thelma and Louise, whose choices in life have been radically curtailed. Lost youth becomes a metaphor for the 
drudgery of taking up our roles in the social world. This metaphor is focused around Louise, the older of the two women who notices the sad, resigned faces of the elderly people she encounters on the road. ${ }^{66}$

Read in general terms that widen narrative address, Thelma and Louise becomes an allegory for breaking free. In publicity interviews, comments about the film from director Ridley Scott and actor Geena Davis speak to the theme of freedom and offer an explanation as to why people who worked on the film believed in its universal appeal. According to Scott, "The film's not about rape. It's about choices and freedom" ${ }^{67}$, and according to Davis, "This is a movie about people claiming responsibility for their own lives." ${ }^{168}$ My intention here is not to challenge the film's address to women, but to suggest there are aspects that speak to an audience of women and men. The film's impressive box-office suggests that it appealed to a wide audience, despite the wrath it elicited from some male film reviewers. ${ }^{69}$ Its economic success would appear to confirm John Fiske's thesis that the more popular a text is, the more polysemic it will be, and therefore, capable of accommodating a range of diverse readings ${ }^{70}$ So the acknowledgment of adult disillusionment that comes to the surface closer to the end of Thelma and Louise, coupled with the reckless excitement that it may not be too late to change things, renders it difficult not to go along with the ride, even if one seriously minds women with guns.

The class and gender (as well as generational) implications of Thelma and Louise's escape become increasingly poignant, particularly in the scene in which the women are driving in the desert at night, on the lookout for police. The spaces in which the two women move open up. The framing, and the panning and tracking shots accommodate the wide-open vistas and big sky of the frontier. Traditionally, the desert has been the landscape of the Hollywood western. ${ }^{71}$ The cowboy doesn't just ride into the sunset in the closing credits - he rides into the desert landscape, choosing the company of his horse, maybe a male buddy, over civilization and all the social conventions entailed (marriage in particular). But the desert frontier is no longer the traditional preserve of white masculinity, as the black Rasta cyclist and the two fugitive women prove. ${ }^{72}$ "I've always wanted to travel but I never got the opportunity," says Thelma. No longer content to be left behind singing sad ballads at the local saloon, Thelma and Louise have elected to go to the desert, metaphorically speaking, even if it means dying. As Thelma says later, when she is afraid Louise might make a deal with the cops, "Something's crossed over in me. I can't go back. I just couldn't live."

Thelma has been married since she was eighteen, but only now does she feel "wide awake ... everything looks different, like I got something to look forward to." For the heroine of the woman's film, the very presence of a desire for something else is literally better than nothing. To be in possession of desire 
in spite of the oppressive social circumstances in which the heroine finds herself makes life somewhat livable - there is something to hope for. The narrative of Thelma and Louise is as much about awakening desires and hopes in the women on the screen as it is about their adventures on the road. As a woman's film, Thelma and Louise draws upon several social experiences that women may share in common (e.g., sexual harassment, the threat of male violence, housework, the salary-wage exchange) as raw material, and then articulates the day-to-day desires and frustrations of its intended female audience in fantasy form. Moreover, there is a sense in which the expression of these female frustrations and resentments via masculine road-movie conventions marks the fantasy as especially illicit, and therefore, all the more pleasurable (and dangerous). Like Thelma, I, too, "am glad I came with you, no matter what happens." Maybe not entirely.

\section{GENDER, GENRE, AND CLOSURE}

The ending of Thelma and Louise has produced almost as much controversy and has generated almost as many conflicting responses as Louise's killing of Harlan. After eluding the police for many days, the two women eventually find themselves cornered, trapped between Hal and his police officers at one end, and the Grand Canyon at the other. The showdown represents the final struggle to contain Thelma and Louise in a definition of femininity and criminality that shores up patriarchal interests. Thelma expresses surprise at the magnitude of force marshaled on their behalf. "All this for us?" she asks. Her incredulity marks her lack of understanding of the threat she and her friend represent. Thelma and Louise like the audience are faced with the consequences of gender transgression.

Hal becomes a personification of the contemporary struggle to re-define gender. He mediates between legal/hegemonic discourses around Thelma and Louise and the two women's experiences of the social world. He desperately wants to arrive at a compromise between the two perspectives. Hal is also a familiar figure in popular film these days: the local cop who attempts to understand the situation in all its complexity and ambiguity unlike the institutionalized authority of the FBI who see the case in simplistic terms. Hal knows about Louise and Texas, and he wants the policemen to refrain from shooting at the two women. Despite his best intentions, Hal doesn't really get it - he is still trying to work within institutions founded on gender-biased assumptions. Moreover, he believes in his ability to act as an individual and to bring about justice within existing institutions. The two women must be apprehended and held accountable because those are the rules under which Hal operates. He does not represent a challenge to the law in the way that Thelma and Louise do, for 
they are not willing to compromise. Hal, on the other hand, is the symbol of compromise, a kinder, gentler patriarch.

Mann maintains that $\mathrm{Hal}$ "shows the future possibility for male desire to alter itself ...." ${ }^{73}$ In other words, Hal represents an emergent masculinity which works in at least two contradictory ways. First, Hal offers a way out for those male audience members made uneasy by the questions around gender and power that the film asks. Hal offers a vision of a patriarchy that is tempered by feminine (not feminist) concerns but that is still in the right. To use a relevant cliché, he is a reformist not a revolutionary. Moreover, as the only positive male stereotype in the film, the implication is that what may be needed are more gentlemanly patriarchs like Hal. Men like him know how to be sweet to their wives, so they won't turn out like Thelma. (Father still knows best, even if no one seems to be listening at the moment.) Second, his struggles to negotiate various ideological interests and beliefs signifies a social order in transition where consensus on a definition of femininity that bolsters male dominance has been irretrievably lost. The last resort is force.

Unlike Hal, the cops represent old-style, status-quo masculinity. Their response to Hal's request to not shoot is that the women are armed. Over a speaker a male voice intones, "Failure to obey is an act of aggression against us," which aptly summarizes the film's primary, motivating conflict: the failure of women to obey will be interpreted by men as an act of aggression against them. And to the end, Thelma and Louise refuse to obey. "Let's not get caught. Let's keep going," says Thelma, and Louise agrees, as the two women clasp hands and kiss in a shot/reverse shot, which, says Putnam, "elevates the friendship between women to the status of heterosexual romance, the end toward which everything is always working in a traditional Hollywood film." ${ }^{.74}$ As they go racing towards the canyon in the blue convertible, Hal runs after them futilely, for the car goes sailing over the cliff. A freeze frame shows the car suspended in mid-air, the shot fades to white, and then, a montage of past scenes showing the women alive and happy rolls during the end credits.

Many critics have argued that one's reading of the ending is genre-dependent. ${ }^{75}$ For instance, Man and Morrison maintain that reading Thelma and Louise as an example of the woman's film means the ending works as a critique of patriarchy, and as such carries subversive connotations. The woman's film is centered around a female protagonist, who in her search for personal fulfillment finds she must contend with societal constraints on her desires. According to Morrison,

What the majority of these female protagonists quickly discover ... is that in the patriarchal society of their diegetic world, there is no place for an active, independent woman .... $[I] t$ is, time and again, only through renunciation and sacri- 
fice that they achieve their ultimate goal; indeed, have any hope of achieving it. Those women who refuse to forego their active desires in effect refuse the possibility of recuperation. Consequently, they almost always are punished by a kind of filmic moral trajectory that brings a double closure, to the woman's life and to the film's narrative. This is not to imply that the cinema is not fascinated with 'bad' women; only that it makes sure that they are not rewarded for their 'crimes' against society. ${ }^{76}$

Both Man and Morrison argue that Thelma and Louise in refusing to compromise their personal desires, reject recuperation by patriarchy. Their suicide is their final act of female self-determination, providing transcendence of the social world. While Morrison sees the two women's deaths "as a victory rather than defeat," Man is more cautious, saying that "Thelma and Louise triumph and they do not." 77

Man's comment encapsulates the contradictory quality of Thelma's and Louise's Pyrrhic victory over patriarchy. To what degree can the ending can be read as progressive, as critical of the status quo? While Thelma and Louise's suicides represent their refusal to capitulate with male dominance, simultaneously, patriarchy's worst fears about disobedient women are excised. Moreover, their deaths suggest there are no alternatives to the existing order. The film can only offer a solution that complies with existing definitions of reality, the law, and gender. This is where Thelma and Louise most demonstrates that it is a hegemonic female fantasy ${ }^{78}$ for it cannot offer a vision of a social world transformed. ${ }^{79}$ This begs the question, to what extent is Thelma and Louise's decision to die actually of their own making or to what extent is it socially predetermined? In other words, even in suicide, Thelma and Louise might not be masters of their own destiny. Instead, they, like this fantasy, accept the limits placed on women rather than fighting to transform their reality.

Yet Thelma and Louise's difference from other backlash representations is its genuine interest in women's social experiences, and its desire to express their fears and frustrations. Even if the film eventually eliminates any alternatives to the status quo, it still envisions a different state. For instance, its critical stance towards the law and its treatment of women victimized by male violence argues that institutional changes are needed. ${ }^{80}$ Moreover, Thelma and Louise presents, however fleetingly, a utopian vision of a life other than the one Thelma and Louise have left behind, a life where the two women put their friendship, their responsibility to each other in solidarity against a common foe, patriarchal authority. As Manohla Dargis says, "Thelma and Louise create a paradigm of female friendship, produced out of their willful refusal of the male 
world and its laws. No matter where their trip finally ends, Thelma and Louise have reinvented sisterhood for the American screen." 81 This is the potentially feminist reading Thelma and Louise produces despite its closure, and that accounts largely for the moralistic, conservative backlash against the film. The images of Thelma and Louise shown during the end credits resonate more powerfully than the vision of their suicidal leap. As the bumper sticker says, "Thelma and Louise live."

Nonetheless, Thelma and Louise's refusal of the male world and its laws is pessimistic. I am left uncomfortable by the need for two women's deaths in order to make a point about patriarchal injustice. At the same time, seeing Thelma and Louise sipping margaritas in Mexico would not be the point either. In the end, Thelma and Louise presents us with the difficulty of envisioning a feminist future in a time when we in Canada and the United States are desperately fighting to keep the gains women's movements have made in the last twenty years - never mind imagining new possibilities. Thelma and Louise's pessimism speaks to this disillusionment. In a time of backlash, the possibility of social transformation may very well require women to join hands and take a leap of faith. While the film is one of the brighter moments in contemporary Hollywood representations of women, it is a rare example, which perhaps suggests the desperation of those of us who were eager to embrace any Hollywood offering that did not feature the woman as the male psycho-killer's object of desire, or as a male-bashing psycho-killer herself, or as the girlfriend of the male lead (who may/may not be a psycho-killer, depending on the genre). Because it is an exception to the usual Hollywood fare, Thelma and Louise may be regarded as an instance of accommodation, a momentary acknowledgment of women's anger and frustration. To put it another way, Thelma and Louise aside, what has Hollywood cinema done for women or for feminism lately?

1 Quoted in Lizzie Francke, Script Girls: Women Screenwriters in Hollywood (London: British Film Institute, 1994), 129.

${ }^{2}$ Susan Faludi, Backlash: The Undeclared War Against American Women (New York: Crown Publishers, 1991), xvii-xix.

${ }^{3}$ Mia Carter, "The Strange Case of Callie Khouri: Public and Private Responses to Thelma and Louise" in Texas Journal of Women and the Law 2, 1 (1993): 134

${ }^{4}$ An interesting aside to the relationship between the book Backlash and the film Thelma und Louise is that author Faludi and screenwriter Khouri became fast friends that same year and continue to have a friendship. According to Vogue's Amy Pagnozzi, the two women's works tended to be cited together by media pundits, raising Khouri's curiosity about a contemporary who was also being attacked as a fascist. Khouri bought a copy of the book and loved it so much, she decided she had to get in touch with Faludi. Khouri says, "... I called her and said, "Okay, we're friends." ${ }^{5}$ Christine Gledhill, "Pleasurable Negotiations" in E. Deidre Pribram, ed., Female Spectators 
Looking at Film and Television (London: Verso, 1988): 69-70.

${ }^{6}$ Other examples include The Accused (1988), Mortal Thoughts (1991), Sleeping with the Enemy (1991), Boys on the Side (1995) and Dolores Clairborne (1995).

${ }^{7}$ Rush Limbaugh is among those ultra right-wing media personalities who helped popularize this term in the early " $90 \mathrm{~s}$.

${ }^{8}$ The term "polysemy", which refers to the notion that the text has multiple meanings, has been used in two ways. In the first usage of polysemy, the text's reception context activates its polysemy. The text is not inherently polysemic: it is its interaction with various reception contexts that produces multiple meanings. In the second usage, the text's production context generates its polysemy. Here, the text is inherently polysemic since it mediates a contingent social formation that comprises contradictory and competing ideological tensions. According to this definition, reception exploits the text's polysemic qualities (cf. Stuart Hall, "Encoding/Decoding" in Stuart Hall et al, eds., Culture, Media, Language: Working Papers in Cultural Studies 1972-79 (London: Hutchinson, 1980), 134). For my purposes, I employ the concept of polysemy in its second usage, as a property of the text. See also John Fiske, [1986] "Television: polysemy and popularity" in Roger Dickinson, Ramaswami Harindranath and Olga Linné, eds., Approaches to Audiences: A Reader (New York: Oxford University Press, 1998), 194-204.

${ }^{9}$ See Carter, 125-31; Brenda Cooper, " 'Chick Flicks' as Feminist Texts: The Appropriation of the Male Gaze in Thelma and Louise" in Women's Studies in Communication 23, 3 (2000): 277-279; Suzanna Danuta Walters, Material Girls: Making Sense of Feminist Cultural Theory (Berkeley and Los Angeles: University of California Press, 1995), 4-10; Sharon Willis, "Hardware and Hardbodies, What Do Women Want?: A Reading of Thelma and Louise" in Jim Collins et al, eds., Film Theory Goes to the Movies. (New York: Routledge and the American Film Institute, 1993): 120-22.

${ }^{10}$ Carter, 126.

11 In Toni and Cynthia Lucia Kamins, eds., "Should We Go Along for the Ride?: A Critical Symposium on Thelma and Louise" in Cineaste 18, 4 (1991): 28-36. See also Cooper, "Chick Flicks", 277-279.

12 Patricia S. Mann, "On the postfeminist frontier" in Socialist Review 24, 2 (1995): 233.

${ }^{13}$ Quoted in Larry Rohter, "The Third Woman of Thelma and Louise" in The New York Times (June 5 1991): C21, C24; cf. Amy Pagnozzi, "Is there life after Thelma and Louise?" Elle 11, 2 (1995):

122. The New York Times headlines for the interview with Khouri call her "The Third Woman of Thelma and Louise" and "The Woman Who Created Thelma and Louise." As Mia Carter points out, "Khouri has been held accountable for her script as few other screenwriters before her."

14 Rohter, C21, C24.

${ }^{15}$ Carl Wayne Arrington, "Lost in America" in Premiere (April 1993): 108.

16 Rohter, C24.

17 Arrington, 108.

${ }^{18}$ Quoted in Rohter, C24.

19 Quoted in A.M. Homes, "Sarandon Transcendent" in Mirabella 75 (1996): 65.

20 Pagnozzi, 122.

${ }^{21}$ Rohter, C24. 
${ }^{22}$ Ann Martin, ed., "The Many Faces of Thelma and Louise" in Film Quarterly 45, 2 (1991-92): 21.

23 Sarandon quoted in Gavin Smith, "Susan Sarandon: Uncompromising Positions" in Film Quarterly 29, 2 (1993): 47.

24 Smith, 49.

${ }^{25}$ Quoted in Smith, 49.

${ }^{26}$ Quoted in Homes, 65

27 Thelma and Louise is the story of two female friends who embark on a weekend getaway that goes awry. Thelma is a frustrated suburban housewife in her early thirties, seeking a brief respite from a domineering husband who has her cloistered in their suburban home. Louise, a middle-aged waitress in a greasy spoon, is fed up with her job and her non-committal boyfriend. As they head out in Louise's blue convertible Thunderbird, the women are excited about the weekend they are going to spend together at a friend's empty cabin. On their way, they stop at a road house for a drink and a bite before continuing on their journey. Here, Thelma dances with a stranger named Harlan who later beats her and tries to rape her in the parking lot. Louise happens upon the scene armed with a gun and saves Thelma. As the two women leave, Harlan hurls insults at them. Louise shoots him dead, and the women find themselves on the run from the law. They decide to head for Mexico. On the road, the women encounter an obnoxious truck driver and a cute cowboy, with whom Thelma has a fling. The cowboy robs them of Louise's savings, the money they were using to get to Mexico. This robbery prompts Thelma to hold up a convenience store. Later, when a police officer stops the two women for speeding, they lock him in the trunk of his cruiser. They make phone contact with Hal, a detective who is trying to track them down and who has knowledge of Louise's past. En route to Mexico, Thelma and Louise talk about their friendship and their lives, and speculate about the nature of crime and responsibility, blame and punishment. Eventually, the law catches up with Thelma and Louise in a spectacular, desert chase-scene in which capture seems inevitable. However, the two friends decide that going back to their old selves would amount to going to prison, so they choose to evade arrest by driving the convertible off a cliff into the Grand Canyon.

${ }^{28}$ Mann, 234.

${ }^{29}$ Cooper, "Chick Flicks," 285-287.

${ }^{30}$ Cf. Susan Morrison, "Girls on Film: Fantasy, Desire and Desperation" in CineACTION! Fall (1985): 2-6 and Jackie Stacey, "Desperately Seeking Difference" in Lorraine Gamman and Margaret Marshment, eds., The Female Gaze: Women as Viewers of Popular Culture (London: The Women's Press, 1988), 112-129.

${ }^{31}$ Homes, 66; Smith, 45.

${ }^{32} \mathrm{Jim}$ Jerome, "Riding Shotgun: In the battle of the sexes, Thelma and Louise's Geena Davis is armed and dangerous" in People Weekly 35, 24 (1991): 92.

${ }^{33}$ Ben Yagoda, "The Prime of Susan Sarandon" in American Film 16, 5 (1991): 25.

${ }^{34}$ Rachel Abramowitz, "Geena Soars" in Premiere (February 1994): 59.

35 Cf. Abramowitz, 56.

36 Jerome, 96.

${ }^{37}$ Cathy Griggers, "Thelma and Louise and the Cultural Generation of the New Butch-Femme" in 
Film Theory Goes to the Movies, 129-141.

38 Carter, 123.

39 In the late ' 80 s and early ' 90 s, kill-your-rapist rhetoric gained notoriety in the mainstream media, which framed it as polarizing several university campuses across Canada and the United States.

${ }^{40}$ In Kamins, 28.

4l Ann Putnam, "The Bearer of the Gaze in Ridley Scott's Thelma and Louise" in Western American Literature 27, 4 (1993): 295-6.

42 Brenda Cooper, "The Relevancy and Gender Identity in Spectators' Interpretations of Thelma and Louise" in Critical Studies in Mass Communication 16 (1999): 30.

${ }^{43}$ Martha Minow and Elizabeth V. Spelman, "Outlaw Women: An Essay on Thelma and Louise" in New England Law Review 26, 4 (1992): 1293.

44 In Kamins, 13.

45 Davis and Khouri quoted in Rohter, C24, C21, respectively

46 Carter, 134

${ }^{47} \mathrm{Cf}$. Grundmann in Kamins, 35.

48 Minow and Spelman, 1290.

${ }^{49}$ Minow and Spelman, 1296.

${ }^{50}$ Glenn Man, "Gender, Genre and Myth in Thelma and Louise" in Film Criticism 18, 1(1993): 44. 5.

${ }^{51}$ Kathi Maio, "Women who murder for the man" in Ms. Magazine 11, 3 (1991): 83.

${ }^{52}$ Cf. Chris Straayer, "The hypothetical lesbian heroine" in Jump Cut 35 (1990): 54-56. In a 2000 article on Thelma and Louise, Cooper theorizes the construction of a female gaze via woman-towoman allegiance. Cooper, " 'Chick Flicks"”.

${ }^{53}$ Minow and Spelman, 1286-7.

${ }^{54}$ Manohla Dargis, "Roads to freedom" in Sight and Sound 1, 3 (1991): 17.

55 Putnam, 296.

${ }^{56}$ Minow and Spelman, 1286.

${ }^{57}$ Maoi, 84.

58 Kamins, 28.

${ }^{59}$ For a further discussion, see Elizabeth Hills, "From 'figurative males' to action heroines: further thoughts on active women in cinema" in Screen 40, 1 (1999): 38-50. She takes issue with how feminist film theory often describes action heroines as "'pseudo males' or as being not 'really' women." For Hill, such a reading strategy misses out on the ways in which "these powerfully trangressive characters open up interesting questions about the fluidity of gendered identities and changing popular cinematic representations of women."

${ }^{60}$ See Linda Alcoff, "Cultural Feminism versus Post-structuralism: The Identity Crisis in Feminist Theory" in Signs 13, 3 (1988): 405-435, for a discussion of the legacy of essentialist feminism (which she terms "cultural feminism") within feminist theory and politics.

${ }^{61}$ Minow and Spelman, 1288.

${ }^{62}$ I agree with Minow and Spelman when they argue that the working-class positions of the men, specifically, Harlan and the trucker, works to justify Thelma and Louise's actions. According to Minow and Spelman, "If class difference may make it safer for many viewers to like Thelma and 
Louise, one might ask whether Harlan and the truck driver seem to deserve what they get because they are presented as working-class men ... No doubt their being working-class men makes it easier for middle-class men to deny that they are like these guys and thus to insist that they surely do not deserve to be treated like Harlan and the truck driver." Moreover, I wonder the degree to which stereotypes of white Southerners adds to our reading of these men as deserving of their fates. Similarly, it would be worth considering how stereotypes of white Southern women may work in relation to readings of Thelma and Louise.

${ }^{63}$ Griggers, 134-5.

${ }^{64}$ In Martin, 22.

${ }^{65}$ Quoted in Francke, 130.

${ }^{66} \mathrm{Cf}$. Johnson in Martin, 23.

${ }^{67}$ Quoted in Amy Taubin, "Ridley Scott's Road Work" in Sight and Sound 1, 3 (1991): 19; cf. Arrington, 107.

${ }^{68}$ Quoted in Minow and Spelman, 1285.

${ }^{69}$ Current Biography states that Thelma and Louise was Scott's most successful film to date. Moreover, in its first two weeks in release, Rohter reports Thelma and Louise made \$12 million at the box office. See Current Biography, "Scott, Ridley" 52, 10 (1991): 511-514.

${ }^{70}$ Fiske, 200.

${ }^{71}$ The desert scenes in Thelma and Louise were shot in Monument Valley, also known as the Utah Canyonlands. This choice of location is significant since Monument Valley appears as the backdrop in many classic John Ford westerns.

72 Dargis, 17.

${ }^{73}$ Mann, 235-6.

${ }^{74}$ Putnam, 301.

${ }^{75}$ In the later stages of writing this paper, I was presented with another possible reading of the cliff scene: that Thelma and Louise do not die. This generally overlooked possibility begs questions as to why crities, even those who were committed to progressive allegorical readings, interpreted the scene according to the terms of realist cinema when the film, because of its mise-en-scène and allegorical narrative, demands to be read as a fantasy. Along these lines, see Willis. When questioned on why she killed off her two characters, Khouri says, "I never thought of it that literally. I never considered they died" (quoted in Pagnozzi, 128). Bumper stickers proclaiming "Thelma and Louise live" indicate that certain female car-owners share Khouri's interpretation.

76 Susan Morrison, "Pearl, Hilda, Thelma and Louise: The Woman's Film Revisited" in CineACTION! 30 (1992): 49.

${ }^{77}$ Morrison, 53; Man, 48.

${ }^{78}$ My use of the term "hegemonic female fantasy" is indebted to Julia Lesage's theorization. See Julia Lesage, "The Hegemonic Female Fantasy in An Unmarried Woman and Craig's Wife" in Film Reader 5 (1982): 83-94.

${ }^{79}$ Cf. Man, 45-6.

${ }^{80}$ Karen Hollinger, In the Company of Women: Contemporary Female Friendships in Films. Minneapolis: University of Minnesota Press 1998), 124-125.

81 Dargis, 18. 